\title{
Identification of the acid phosphatase (acpA) gene homologues in pathogenic and non- pathogenic Burkholderia spp. facilitates TnphoA mutagenesis
}

Dept of Microbiology and Infectious Diseases, University of Calgary, 3330 Hospital Drive NW, Calgary, Alberta, Canada

\author{
Mary N. Burtnick, Alexandra J. Bolton, Paul J. Brett, David Watanabe \\ and Donald E. Woods
}

Author for correspondence: Donald E. Woods. Tel: +1 403220 2564. Fax: +1 4032835241.

e-mail:woods@ucalgary.ca

\begin{abstract}
Burkholderia pseudomallei and Burkholderia mallei are pathogens responsible for disease in both humans and animals. Burkholderia thailandensis, while phylogenetically similar, is considered avirulent in comparison. These three species exhibit phosphatase activity when grown on media containing chromogenic substrates such as 5-bromo-4-chloro-3-indolyl phosphate (XP). Tn5-0T182 mutagenesis has been utilized to isolate mutants of $B$. pseudomallei and $B$. thailandensis unable to hydrolyse XP. Sequence analysis of these mutants revealed an ORF of 1734 nucleotides demonstrating a high degree of homology to the acpA gene product of Francisella tularensis. PCR primers were designed based on the $B$. pseudomallei acp $A$ gene sequence and were used to amplify an acpA homologue from $B$. mallei. The predicted amino acid sequence of B. pseudomallei AcpA differed from those of the predicted B. thailandensis AcpA and B. mallei AcpA by 15 and 3 amino acids, respectively. Allelic exchange was used to construct $\triangle$ acpA mutants in each of these Burkholderia spp. These mutants were shown to be devoid of phosphatase activity and have subsequently allowed for the implementation of phoA fusion transposon mutagenesis systems. Two such systems have been successfully utilized in Burkholderia spp. for the identification of several genes encoding exported proteins.
\end{abstract}

Keywords: Burkholderia spp., acid phosphatase, TnphoA, exported proteins

\section{INTRODUCTION}

Burkholderia pseudomallei, Burkholderia thailandensis and Burkholderia mallei are three closely related Gramnegative bacteria. B. pseudomalle $i$ is the causative agent of melioidosis, a disease endemic to South-east Asia and Northern Australia (Smith et al., 1987) while B. mallei is the causative agent of glanders, an equine zoonosis (Arun et al., 1999). B. thailandensis is an avirulent species that is genetically very similar to $B$. pseudomalle $i$ and B. mallei; however, it lacks at least one pathogenicity island present in these species (Brett et al., 1998; Reckseidler et al., 2001). Melioidosis and glanders have

Abbreviations: AP, acid phosphatase; XP, 5-bromo-4-chloro-3-indolyl phosphate.

The GenBank accession numbers for the sequences reported in this paper are AF252862, AF252863 and AF276770. relatively high mortality rates and studies to elucidate the factors that contribute to their pathogenesis are necessary. B. thailandensis is a particularly useful laboratory tool for genetic manipulations under avirulent conditions which may contribute to the understanding of functions common to $B$. pseudomallei and $B$. mallei.

B. pseudomallei and B. mallei synthesize a variety of secreted enzymes (DeShazer et al., 1999) and surface antigens; however, the roles of such factors in the pathogenesis of the diseases caused by these organisms remain poorly defined. To define the role(s) of particular exported proteins in pathogenesis, it is necessary to employ a system in which defined mutations can be made in genes encoding such products. The system we have chosen to investigate and implement in this study is the TnphoA fusion vector system. The phoA gene fusion approach relies on the fact that the periplasmic bacterial 
alkaline phosphatase (PhoA) must be located extracytoplasmically for enzymic activity to occur (Taylor et al., 1989; Manoil \& Beckwith, 1985). TnphoA utilizes a Tn5 transposon containing a truncated phoA gene which lacks a signal sequence; this transposon can generate $p h o A$ gene fusion randomly upon integration into the recipient bacterial chromosome (Taylor et al., 1989; Manoil \& Beckwith, 1985). If the targeted gene encodes an exported protein then the hybrid protein expressed will exhibit PhoA activity and the resulting colony will appear blue when grown on medium containing the chromogenic substrate 5-bromo-4chloro-3-indoyl-phosphate (XP). Due to the fact that exported proteins are frequently involved in pathogenesis, this system provides a means by which the selection for the identification of virulence genes is enhanced. There are a number of instances in the literature in which $\operatorname{Tn} p h o A$ mutagenesis has been used successfully for the identification of virulence factors. Some examples include involvement of OmpA in the virulence in Escherichia coli K-1 (Weiser \& Gotschlich, 1991), identification of OMPs in the pathogenesis of Salmonella abortusovis (Rubino et al., 1993), characterization of virulence genes of enteroinvasive $E$. coli (Hsia et al., 1993), recognition that TnphoA mutants in penicillin-binding proteins from Erwinia amylovora are avirulent (Milner et al., 1993) and identification of antigens involved in colonization of Vibrio cholerae O139 (Bondre et al., 1997).

B. pseudomallei exhibits phosphatase activity when grown on agar containing XP. To implement a phoA gene fusion system in $B$. pseudomallei, a strain that cannot hydrolyse XP must be utilized. It is known that some of this phosphatase activity is due to a surfacebound glycoprotein possessing acid phosphatase (AP) activity (Kanai \& Kondo, 1994; Kondo et al., 1996). However, the gene encoding an AP has remained unidentified prior to this study. In the present study we describe the sequence of the AP (acpA) gene homologues present in $B$. pseudomallei, B. thailandensis and $B$. mallei. The AP activity associated with the acpA gene product was assessed. The inactivation of the acpA gene homologues and subsequent complementation confirms that the acpA gene product is responsible for the AP activity present in these species. In addition, strains harbouring disrupted acpA gene homologues were constructed and have allowed for mutagenesis using TnphoA (Manoil \& Beckwith, 1985) and mini-OphoA (Bolton \& Woods, 2000) for the identification of genes involved in the production of exported proteins in these Burkholderia spp.

\section{METHODS}

Bacterial strains, plasmids and growth conditions. The bacterial strains and plasmids used in this study are shown in Table 1. B. pseudomalle $i$ and B. thailandensis cultures were incubated at $37^{\circ} \mathrm{C}$ on Luria-Bertani (LB) agar plates or in LB broth with agitation at 250 r.p.m. B. mallei cultures were grown at $37^{\circ} \mathrm{C}$ on tryptic soy agar supplemented with $4 \%$ glycerol (TSG) or in TSG broth. Antibiotics were purchased from Sigma and Invitrogen. For E. coli, antibiotics were used at the following concentrations: $100 \mu \mathrm{g}$ ampicillin (Ap) $\mathrm{ml}^{-1}$, $25 \mu \mathrm{g}$ kanamycin $(\mathrm{Km}) \mathrm{ml}^{-1}, \quad 25 \mu \mathrm{g}$ chloramphenicol $(\mathrm{Cm}) \mathrm{ml}^{-1}, 100 \mu \mathrm{g}$ streptomycin $(\mathrm{Sm}) \mathrm{ml}^{-1}, 15 \mu \mathrm{g}$ gentamicin $(\mathrm{Gm}) \mathrm{ml}^{-1}, 15 \mu \mathrm{g}$ tetracycline $(\mathrm{Tc}) \mathrm{ml}^{-1}, 50 \mu \mathrm{g}$ polymyxin $\mathrm{B}$ $(\mathrm{Pm}) \mathrm{ml}^{-1}, 1.5 \mathrm{mg}$ trimethoprim $(\mathrm{Tp}) \mathrm{ml}^{-1}$ and $25 \mu \mathrm{g}$ zeocin (Ze) $\mathrm{ml}^{-1}$. For B. pseudomallei and B. thailandensis the antibiotic concentrations used were $50 \mu \mathrm{g} \mathrm{Km} \mathrm{ml}{ }^{-1}, 50 \mu \mathrm{g}$ $\mathrm{Tc} \mathrm{ml}^{-1}, 100 \mu \mathrm{g} \mathrm{Tp} \mathrm{ml}{ }^{-1}$ and $100 \mu \mathrm{g} \mathrm{Ze} \mathrm{ml}{ }^{-1}$ unless otherwise stated. For B. mallei antibiotic concentrations used were $75 \mu \mathrm{g}$ naladixic acid $(\mathrm{Nx}) \mathrm{ml}^{-1}, 5 \mu \mathrm{g} \mathrm{Km} \mathrm{ml} \mathrm{K}^{-1}, 5 \mu \mathrm{g} \mathrm{Ze} \mathrm{ml} \mathrm{g}^{-1}, 15 \mu \mathrm{g}$ $\mathrm{Pm} \mathrm{ml}^{-1}$ and $5 \mu \mathrm{g} \mathrm{Gm} \mathrm{ml} \mathrm{m}^{-1}$.

Plasmids were purified using the Concert rapid plasmid miniprep system (GibcoBRL), QIAprep spin plasmid miniprep kit (Qiagen) or QIAprep midipreps for plasmid DNA (Qiagen).

Tn5-OT182 mutagenesis and screening. B. pseudomallei $1026 \mathrm{~b}$ and B. thailandensis E264 were mutagenized with Tn5OT182 as previously described (DeShazer et al., 1997). B. pseudomallei conjugations were incubated at $37^{\circ} \mathrm{C}$ for $8 \mathrm{~h}$ while those of $B$. thailandensis were incubated at $37^{\circ} \mathrm{C}$ for $2 \mathrm{~h}$. Transconjugants were selected for on LB agar plates

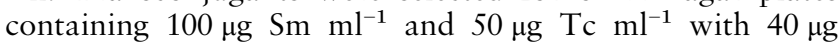
$\mathrm{XP} \mathrm{ml} \mathrm{m}^{-1}$. White colonies were retained for further analyses.

DNA manipulation and transformations. Restriction endonucleases and T4 DNA ligase were purchased from GibcoBRL and New England Biolabs, respectively, and were used according to the manufacturers' instructions. DNA fragments excised from agarose gels and used in cloning procedures were purified using a QIAquick gel extraction kit (Qiagen). A Wizard genomic DNA purification kit (Promega) was used for isolation of genomic DNA from bacterial strains. The DNA immediately flanking Tn5-OT182 integrations was self-cloned as previously described (DeShazer et al., 1997). In brief, approximately $5 \mu \mathrm{g}$ chromosomal DNA from Tn5-OT182 mutants was digested with restriction enzyme, boiled for 5 min and precipitated with $0 \cdot 1$ vol. $3 \mathrm{M}$ sodium acetate and 2 vols $100 \%$ ethanol. This mixture was placed at $-70{ }^{\circ} \mathrm{C}$ for at least $30 \mathrm{~min}$, centrifuged and washed with $70 \%$ ethanol. The resulting DNA was air-dried, resuspended in distilled water and ligation reactions were prepared. Transformations were performed with 2-10 $\mu$ l ligation mixture using chemically competent E. coli cells.

Phosphatase activity assays. AP activity assays were performed in triplicate using a previously described method (Kondo et al., 1991b, 1996). Supernatants, periplasmic proteins and whole cells were prepared from $1 \mathrm{ml}$ of overnight cultures grown at $37^{\circ} \mathrm{C}$. Supernatants were harvested and filter-sterilized through a $0.22 \mu \mathrm{m}$ filter (Millipore) for use in supernatant assays. Whole cells were pelleted, resuspended in $1 \mathrm{ml} \mathrm{0.01} \mathrm{M} \mathrm{Tris/} \mathrm{HCl} \mathrm{pH} 8.0$ and used in whole-cell assays. Periplasmic proteins were extracted using a previously described chloroform extraction method (Ames et al., 1984). In a typical assay, $20 \mu \mathrm{l}$ of the test sample, $20 \mu \mathrm{l} p$-nitrophenyl phosphate $(0 \cdot 2 \%, \mathrm{w} / \mathrm{v}$, solution) and $160 \mu \mathrm{l} 0 \cdot 1 \mathrm{M}$ sodium acetate buffer $\mathrm{pH} 5.5$ were mixed and incubated at $37^{\circ} \mathrm{C}$ for $30 \mathrm{~min}$ in microtitre wells. Then $100 \mu \mathrm{l} 0.5 \mathrm{M} \mathrm{NaOH}$ was added and the colour was allowed to develop for $5 \mathrm{~min}$. Plates were read at $405 \mathrm{~nm}$.

PCR amplification and cloning of PCR products. The acpA gene homologues were amplified from B. pseudomallei $1026 \mathrm{~b}$ and B. mallei ATCC 23344 chromosomal DNA via PCR. The oligodeoxyribonucleotide primers used were AP-5' (GCTCTAGACGAGCGGACGGGAAATGGCG) contain- 
Table 1. Strains and plasmids used in this study

\begin{tabular}{|c|c|c|}
\hline Strain or plasmid & Description & Reference \\
\hline \multicolumn{3}{|l|}{ Strains } \\
\hline \multicolumn{3}{|c|}{ 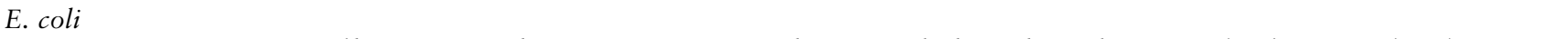 } \\
\hline $\mathrm{DH} 5 \alpha$ & $\begin{array}{l}\mathrm{F}^{-} \phi 80 \mathrm{~d} l a c Z \Delta \mathrm{M} 15 \Delta(\text { lacZYA-argF }) \mathrm{U} 169 \text { endA1 recA1 hsdR17 deoR thi-1 } \\
\text { supE44 gyrA96 relA1 }\end{array}$ & Bethesda Research Laboratories \\
\hline Top 10 & $\begin{array}{l}\mathrm{F}^{-} \text {mcrA } \Delta(\text { mrr-hsdRMS-mcrBC }) \phi 80 \text { lacZ } \Delta \mathrm{M} 15 \Delta \text { lacX74 deoR recA1 } \\
\text { araD139 } \Delta(\text { ara-leu }) 7697 \text { gall galK rpsL }\left(\mathrm{Sm}^{\mathrm{R}}\right) \text { endA1 nupG }\end{array}$ & Invitrogen \\
\hline SM10 $\lambda p i r$ & SM10 with a $\lambda$ prophage carrying the gene & Miller \& Mekalanos (1988) \\
\hline \multicolumn{3}{|l|}{ B. pseudomallei } \\
\hline $1026 \mathrm{~b}$ & Clinical isolate (human); $\mathrm{Km}^{\mathrm{R}} \mathrm{Gm}^{\mathrm{R}} \mathrm{Pm}^{\mathrm{R}} \mathrm{Sm}^{\mathrm{R}} \mathrm{Tc}^{\mathrm{S}}$ & DeShazer et al. (1997) \\
\hline DD503 & $\begin{array}{l}\text { 1026b derivative; allelic exchange strain; } \Delta(\operatorname{amrR}-o p r A) ; \mathrm{Km}^{\mathrm{s}} \mathrm{Gm}^{\mathrm{s}} \mathrm{Sm}^{\mathrm{s}} \\
r p s L \mathrm{Sm}^{\mathrm{R}}\end{array}$ & Moore et al. (1999) \\
\hline APM402 & 1026b derivative; ORF::Tn5-OT182 & This study \\
\hline APM403 & 1026b derivative; $a p c A:: \operatorname{Tn} 5-O T 182$ & This study \\
\hline APM403C & APM403 (p29acpA) & This study \\
\hline MB401Z & DD503 derivative; $a c p A \Delta($ nt $1-1139)$ : : shble-p15Aori; $\mathrm{Ze}^{\mathrm{R}}$ & This study \\
\hline MB401 & DD503 derivative; $\operatorname{acp} A \Delta($ nt $1-1139)$ & This study \\
\hline \multicolumn{3}{|l|}{ B. thailandensis } \\
\hline E264 & Environmental isolate; $\mathrm{Km}^{\mathrm{R}} \mathrm{Gm}^{\mathrm{R}} \mathrm{Pm}^{\mathrm{R}} \mathrm{Sm}^{\mathrm{R}} \mathrm{Tc}^{\mathrm{s}}$ & Brett et al. (1998) \\
\hline DW503 & 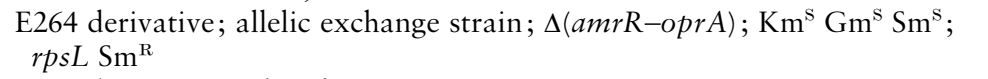 & This study \\
\hline APM501 & E264 derivative; $u d p-r f a H:: \operatorname{Tn} 5-\mathrm{OT} 182$ & This study \\
\hline APM502 & E264 derivative; $a p c A:: \operatorname{Tn} 5-O T 182$ & This study \\
\hline APM501C & APM501 (p29acpA) & This study \\
\hline DW401Z & 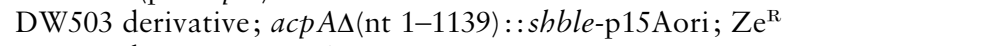 & This study \\
\hline DW401 & DW503 derivative; acpA $\Delta(\mathrm{nt} 1-1139)$ & This study \\
\hline \multicolumn{3}{|l|}{ B. mallei } \\
\hline $\begin{array}{l}\text { ATCC } 23344 \\
\text { (formerly GB8) }\end{array}$ & Clinical isolate (equine) & USAMRIID \\
\hline G8N & ATCC 23344 derivative; $\mathrm{Nx}^{\mathrm{R}}$ & This study \\
\hline G8P & ATCC 23344 derivative; acpAs(nt 1-1139)::shble-p15oriV; Ze $\mathrm{e}^{\mathrm{R}}$ & This study \\
\hline G8PN & G8P derivative; $\mathrm{Ze}^{\mathrm{R}} \mathrm{Nx}^{\mathrm{R}}$ & This study \\
\hline \multicolumn{3}{|l|}{ Plasmids } \\
\hline pOT182 & pSUP102(Gm):: Tn5-OT182; $\mathrm{Cm}^{\mathrm{R}} \mathrm{Gm}^{\mathrm{R}} \mathrm{Ap}^{\mathrm{R}} \mathrm{Tc}^{\mathrm{R}}$ & Merriman \& Lamont (1993) \\
\hline pUC19 & Cloning vector & New England Biolabs \\
\hline pCR2.1TOPO & Cloning vector; $\mathrm{pUC}$ ori; $\mathrm{Ap}^{\mathrm{R}} \mathrm{Km}^{\mathrm{R}}$ & Invitrogen \\
\hline pUCP29T & Broad-host-range vector; IncP OriT; pRO1600 ori; Tp ${ }^{R}$ & Schweizer et al. (1996) \\
\hline p34EoriZeo & $\begin{array}{l}\text { Vector containing self-cloning } \mathrm{Ze}^{\mathrm{R}} \text { cassette; shble-p15oriV; this vector } \\
\text { was derived from p34Eori and the Zeo cassette from pEM7/Zeo } \\
\text { (Invitrogen) }\end{array}$ & $\begin{array}{l}\text { P. J. Brett, D. DeShazer, M. N. } \\
\text { Burtnick \& D. E. Woods, } \\
\text { unpublished }\end{array}$ \\
\hline pKAS46 & Allelic exchange vector; $r p s L \mathrm{Sm}^{\mathrm{s}}$ & Skorupski \& Taylor (1996) \\
\hline pAPM $402 \mathrm{E}$ & $0.7 \mathrm{~kb}$ EcoRI fragment from APM402 obtained by self-cloning; $\mathrm{Ap}^{\mathrm{R}} \mathrm{Tc}^{\mathrm{R}}$ & This study \\
\hline pAPM403E & 8.0 kb EcoRI fragment from APM403 obtained by self-cloning; $\mathrm{Ap}^{\mathrm{R}} \mathrm{Tc}^{\mathrm{R}}$ & This study \\
\hline pAPM $403 \mathrm{H}$ & $5.5 \mathrm{~kb}$ HindIII fragment from APM403 obtained by self-cloning; $\mathrm{Ap}^{\mathrm{R}} \mathrm{Tc}^{\mathrm{R}}$ & This study \\
\hline pAPM501Ss & $1.6 \mathrm{~kb}$ SstI fragment from APM501 obtained by self-cloning; $\mathrm{Ap}^{\mathrm{R}} \mathrm{Tc}^{\mathrm{R}}$ & This study \\
\hline pAPM501H & $6.5 \mathrm{~kb}$ HindIII fragment from APM501 obtained by self-cloning; $\mathrm{Ap}^{\mathrm{R}} \mathrm{Tc}^{\mathrm{R}}$ & This study \\
\hline pAPM502E & $0.5 \mathrm{~kb}$ EcoRI fragment from APM502 obtained by self-cloning; $\mathrm{Ap}^{\mathrm{R}} \mathrm{Tc}^{\mathrm{R}}$ & This study \\
\hline pMB401 & $\begin{array}{l}\text { pUC19 containing } 4.5 \mathrm{~kb} \mathrm{HpaI} / \text { Sst I fragment containing nt } 1-1633 \text { of the } \\
\text { acpA gene }\end{array}$ & This study \\
\hline pMB401X & pMB401 $\Delta(2 \cdot 8 \mathrm{~kb}$ XhoI fragment $)$ & This study \\
\hline pMB401Z & pMB401 $\Delta(2 \cdot 8 \mathrm{~kb}$ XhoI fragment $) ;$ shble-p15AoriV; $\mathrm{Ze}^{\mathrm{R}}$ & This study \\
\hline p46MB401X & pKAS46 containing $1.3 \mathrm{~kb}$ SstI/HindIII fragment from pMB401X & This study \\
\hline $\mathrm{p} 46 \mathrm{MB} 401 \mathrm{Z}$ & pKAS46 containing $2.7 \mathrm{~kb}$ SstI/HindIII fragment from $\mathrm{pMB} 401 \mathrm{Z} ; \mathrm{Ze}^{\mathrm{R}}$ & This study \\
\hline $\mathrm{p} 29$ acp $A$ & $\begin{array}{l}\text { pUCP29T with } 1.8 \mathrm{~kb} X b a \mathrm{I} / \mathrm{KpnI} \text { fragment containing } B \text {. pseudomallei } \\
\text { acpA gene }\end{array}$ & This study \\
\hline pRT733 & oriR6K mobRP4 TnphoA; $\mathrm{Ap}^{\mathrm{R}} \mathrm{Km}^{\mathrm{R}}$ & Taylor et al. (1989) \\
\hline pmini-OphoA & pMB1 oriR, Tn5 tnp, RP4 oriT, phoA; $\mathrm{Gm}^{\mathrm{R}}$ & Bolton \& Woods (2000) \\
\hline pBR322 & Cloning vector oriColE1; $\mathrm{Ap}^{\mathrm{R}} \mathrm{Tc}^{\mathrm{R}}$ & New England Biolabs \\
\hline
\end{tabular}


(a)

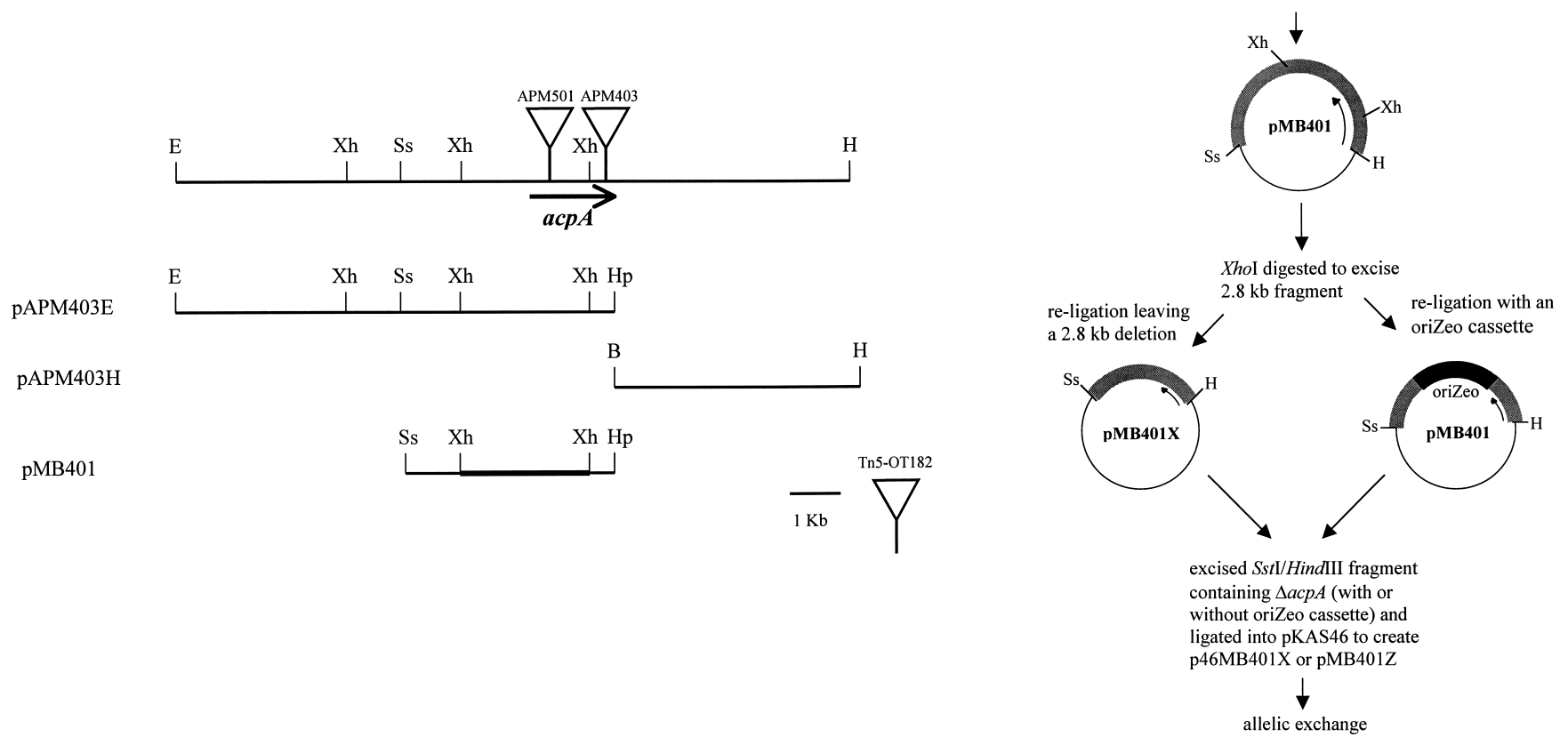

$4.5 \mathrm{~kb}$ Sst $\mathrm{I} / \mathrm{HpaI}$ (klenow treated) fragment from pAPM403E was ligated into $S s t / / S m a I$ digested pUC19 to create pMB40

Fig. 1. (a) Plasmids containing acpA genes used in this study. Relative locations of Tn5-OT182 integrations in the acpA gene (black arrow) in AP-negative mutants, APM403 and APM501, are shown. Fragments obtained by self-cloning are shown, pAPM403E and pAPM403H. The fragment from pMB401 used for construction of strains for use in TnphoA mutagenesis is also shown; the $2.8 \mathrm{~kb}$ fragment deleted encompassing nucleotides 1-1139 of the acpA gene is shown as a thicker black line. (b) Scheme used for deletion of a portion of the B. pseudomallei acpA gene (black arrow on inside of plasmid) and subsequent construction of vectors for allelic exchange. Restriction sites are as follows: EcoRI (E), HindIII (H), Xhol (Xh), Sstl (Ss), Hpal (Hp) and BamHI (B). The Hp and B sites were located on the ends of Tn5-OT182.

ing an Xbal linker and AP-3' (GGGGTACCTCTTGTCTACCGTACCGACC) containing a KpnI linker (linkers underlined). PCR amplification was performed in $100 \mu \mathrm{l}$ reaction mixtures containing approximately $500 \mathrm{ng}$ genomic DNA, $1 \times$ PCR buffer (GibcoBRL), a $200 \mathrm{mM}$ concentration of each deoxynucleoside triphosphate, a $0.5 \mathrm{mM}$ concentration of each primer, $2 \mathrm{mM} \mathrm{MgCl}_{2}$ (GibcoBRL), $1 \times \mathrm{Q}$ solution (Qiagen) and $5 \mathrm{U}$ Taq DNA polymerase (GibcoBRL) per $\mu$ l. This mixture was placed in a GeneAmp PCR system 9600 (Perkin-Elmer Cetus) thermal cycler and subjected to a 5 min denaturation step at $95^{\circ} \mathrm{C}$ followed by 30 cycles at $95^{\circ} \mathrm{C}$ for $45 \mathrm{~s}, 56^{\circ} \mathrm{C}$ for $30 \mathrm{~s}$ and $72{ }^{\circ} \mathrm{C}$ for $90 \mathrm{~s}$. The reaction mixture was next held at $72{ }^{\circ} \mathrm{C}$ for $10 \mathrm{~min}$ and then placed at $4{ }^{\circ} \mathrm{C}$ until analysed on a $1 \%$ agarose gel. The resulting PCR products were digested with $K p n \mathrm{I}$ and $\mathrm{Xba \textrm {I }}$ and cloned into pUC19 or cloned directly into pCR2.1TOPO (Invitrogen) using a TOPO TA Cloning Kit (Invitrogen). The cloned PCR products were sequenced on both strands.

Construction of allelic exchange mutants. Allelic exchange was performed in B. pseudomallei DD503 and B. thailandensis DW503 using the rpsL-based vector pKAS46 as previously described (Moore et al., 1999; Skorupski \& Taylor, 1996). Both DD503 and DW503 are $\mathrm{Sm}^{\mathrm{s}}$ due to deletion of the amrR-oprA operon, but $\mathrm{Sm}^{\mathrm{R}}$ due to a mutation in the $r p s L$ gene (Moore et al., 1999). Allelic exchange experiments in the present study employed the vectors p46MB401Z or p46MB401X, which were constructed using a deleted version of the acpA gene homologue from B. pseudomallei. The steps in construction of these vectors are described below and are also shown in Fig. 1(b). A $4.5 \mathrm{~kb} \mathrm{SstI/HpaI} \mathrm{(Klenow-treated)}$ fragment containing nucleotides 1 to 1633 of the acpA gene was excised from pAPM403E and inserted into pUC19, creating pMB401. A $2 \cdot 8 \mathrm{~kb}$ Xhol fragment was then excised from pMB401 and the vector was ligated back together with or without an oriZeo cassette, resulting in pMB401X or pMB401Z. Each of these fragments containing the $\Delta a c p A$ gene homologue was separately inserted into pKAS46 to create p46MB401Z or p46MB401X. SM10 ipir strains containing these vectors were used in conjugation experiments with either DD503 or DW503. Transconjugants were selected for on LB agar containing $50 \mu \mathrm{g} \mathrm{Pm} \mathrm{m}{ }^{-1}, 50 \mu \mathrm{g} \mathrm{Km} \mathrm{ml}{ }^{-1}$ and $100 \mu \mathrm{g}$ $\mathrm{Ze} \mathrm{ml}^{-1}$ when appropriate. Transconjugants were subsequently plated on $100 \mu \mathrm{g} \mathrm{Sm} \mathrm{ml}{ }^{-1}$ alone or with $100 \mu \mathrm{g} \mathrm{Ze} \mathrm{ml} \mathrm{m}^{-1}$ to select for loss of the vector. These mutants were plated on LB agar plates containing $50 \mu \mathrm{g} \mathrm{Km} \mathrm{m}^{-1}$ to confirm a double crossover event as indicated by lack of growth. Allelic exchange mutants were confirmed by Southern blot analysis.

A slightly different strategy was used for allelic exchange in $B$. mallei, because spontaneous $\mathrm{Sm}^{\mathrm{R}}$ mutants of ATCC 23344 were also Sm dependent, i.e. these mutants could not grow in the absence of $\mathrm{Sm}$. To overcome this problem, transconjugants from ATCC 23344 and SM10 $\lambda$ pir(p46MB401Z) mutagenesis were selected for on TSG agar containing $80 \mu \mathrm{g} \mathrm{XP} \mathrm{ml}{ }^{-1}, 15 \mu \mathrm{g}$

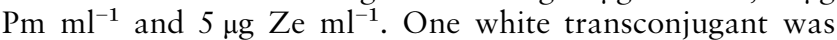
$\mathrm{Km}^{\mathrm{s}}$, indicating loss of the vector (pKAS46) and thus, a double crossover event. This mutant was designated G8P. A spontaneously $\mathrm{Nx}^{\mathrm{R}}$ derivative of $\mathrm{G} 8 \mathrm{P}$ was selected for and obtained because $\mathrm{Nx}$ provided better selection than Pm. This $\mathrm{Nx}^{\mathrm{R}} \mathrm{Ze}^{\mathrm{R}}$ XP-negative strain of B. malle $i$ was designated G8PN and was used for further assessment. 
Complementation of Tn5-OT182 mutants. A wild-type copy of the acpA gene obtained by PCR from $B$. pseudomalle $i$ $1026 \mathrm{~b}$ DNA was cloned into the broad-host-range vector pUCP29T. This construct, designated p29acpA, was transformed into $E$. coli SM10 ipir and conjugated to $B$. pseudomallei APM403 and B. thailandensis APM501 for $5 \mathrm{~h}$, followed by selection on LB agar plates containing $100 \mu \mathrm{g}$

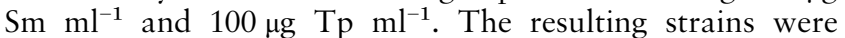
inoculated on similar LB agar plates with $40 \mu \mathrm{g} \mathrm{XP} \mathrm{ml}^{-1}$ and blue colonies were retained.

TnphoA and mini-OphoA mutagenesis. In a typical TnphoA mutagenesis experiment, approximately $5 \mu \mathrm{l}$ of an overnight culture of SM10 $\lambda$ pir(pRT733) containing TnphoA and $5 \mu$ l of either B. pseudomallei MB401Z or B. thailandensis DW401Z were mixed together on an LB agar plate and incubated at $37^{\circ} \mathrm{C}$ for $18 \mathrm{~h}$. Eight to ten separate conjugations were carried out on a single plate concurrently along with donor and recipient alone as controls. Each individual conjugation was plated on a single agar plate. B. pseudomallei and $B$. thailandensis transconjugants were selected for on LB agar containing $300 \mu \mathrm{g} \mathrm{Km} \mathrm{ml}^{-1}, 100 \mu \mathrm{g} \mathrm{Sm} \mathrm{m}^{-1}, 100 \mu \mathrm{g} \mathrm{Ze} \mathrm{ml}{ }^{-1}$ and $40 \mu \mathrm{g} \mathrm{XP} \mathrm{ml}^{-1}$. For B. mallei G8PN a similar procedure was employed except that transconjugants were selected for on TSG agar plates containing $5 \mu \mathrm{g} \mathrm{Km} \mathrm{m}{ }^{-1}, 75 \mu \mathrm{g} \mathrm{Nx} \mathrm{ml}{ }^{-1}$, $5 \mu \mathrm{g} \mathrm{Ze} \mathrm{ml}{ }^{-1}$ and $80 \mu \mathrm{g} \mathrm{XP} \mathrm{ml} l^{-1}$. Plates were incubated at $37^{\circ} \mathrm{C}$ for $48 \mathrm{~h}$ and blue colonies were retained for further analysis. The DNA immediately flanking the $\operatorname{Tn} p h o A$ integration was cloned as previously described (Taylor et al., 1989) using the cloning vector pBR322 and BamHI- or SalI-digested genomic DNA. The resulting plasmids were sequenced using a previously described primer sequence (Taylor et al., 1989)

Mini-OphoA was constructed using the Tn5-based plasposon pTnModOGm (Dennis \& Zylstra, 1998) and the phoA gene from pRT733 (TnphoA) (Manoil \& Beckwith, 1985). Mini$\mathrm{O} p h o A$ is small $(3.4 \mathrm{~kb})$ and contains an origin of replication that allows for self-cloning of the chromosomal DNA adjacent to transposon integrations (Bolton \& Woods, 2000). B. pseudomallei MB401, B. thailandensis DW401 and B. mallei G8PN strains were recipient strains for mini-OphoA mutagenesis experiments. Conjugations were performed as described for $\operatorname{Tn} p h o A$ using $5 \mu$ l of donor and recipient strains on LB or TSG agar plates at $37^{\circ} \mathrm{C}$ for $18 \mathrm{~h}$. Transconjugants of $B$. pseudomallei and B. thailandensis were selected for on LB agar plates containing $100 \mu \mathrm{g} \mathrm{Sm} \mathrm{ml}^{-1}, 15 \mu \mathrm{g} \mathrm{Gm} \mathrm{ml}^{-1}$ and $40 \mu \mathrm{g} \mathrm{XP} \mathrm{ml^{-1 }}$. B. mallei transconjugants were selected for on TSG agar plates containing $5 \mu \mathrm{g} \mathrm{Gm} \mathrm{ml} l^{-1}, 75 \mu \mathrm{g} \mathrm{Nx} \mathrm{ml}^{-1}, 5 \mu \mathrm{g}$ $\mathrm{Ze} \mathrm{ml}^{-1}$ and $80 \mu \mathrm{g} \mathrm{XP} \mathrm{ml} \mathrm{C}^{-1}$. Self-cloning of the DNA immediately flanking mini-OphoA integrations was performed essentially as previously described for Tn5-OT182 (DeShazer et al., 1997). Briefly, genomic DNA of mutants harbouring mini-OphoA was isolated then digested with $\mathrm{Not}$ I at $37^{\circ} \mathrm{C}$ for $1 \mathrm{~h}$. These reactions were then heat-inactivated followed by ethanol precipitation. Ligation reactions were set up for $1 \mathrm{~h}$ at room temperature or overnight at $16^{\circ} \mathrm{C}$ then transformed into chemically competent E. coli DH5 $\alpha$ or Top 10 cells. The resulting plasmids were isolated and sequenced.

DNA sequencing and analysis. DNA sequencing was performed by University Core DNA Services (University of Calgary). The previously described oligodeoxyribonucleotide primers OT182-RT and OT182-LT (DeShazer et al., 1997) were used for sequencing of plasmid DNA obtained by selfcloning of Tn5-OT182 mutants. The previously described primer sequence (5'-AATATCGCCCTGAGC-3') was used for sequencing plasmids from $\operatorname{Tn} p h o A$ clones obtained in this study (Taylor et al., 1989). Two deoxyoligonucleotide primers, Pho-LT (5'-CAGTAATATCGCCCTGAGCAGC$\left.3^{\prime}\right)$ and Gm-RT (5'-GCCGCGCAATTCGAGCTC-3'), were used for sequencing the mini-OphoA clones (Bolton \& Woods, 2000). Custom-designed primers were synthesized by University Core DNA Services and used in a primer walking strategy to obtain the sequence of both strands of the acpA gene homologue.

The DNA sequences obtained in this study were analysed using DNASIS v2.5 (Hitachi) and DIALIGN 2.1 (Morgenstern, 1999) for the presence of ORFs and restriction endonuclease cleavage sites, for sequence alignment and for translation to amino acid sequences. BLASTX and BLASTP programs were used to perform database searches in order to establish homology to known gene sequences (Altschul et al., 1997).

The acpA gene sequences from B. pseudomallei, B. thailandensis and B. mallei were submitted to GenBank under accession nos AF252862, AF252863 and AF276770, respectively.

\section{RESULTS}

\section{Identification of acpA homologues from B. pseudomallei, B. thailandensis and B. mallei}

To identify and characterize the gene or genes responsible for the phosphatase activity exhibited by $B$. pseudomallei, we chose to employ Tn5-OT182 mutagenesis in combination with a simple screen in which the chromogenic substrate XP was incorporated into LB agar plates. Approximately 7000 B. pseudomallei Tn5OT182 mutants were plated onto media containing XP. Two mutants were identified that were unable to hydrolyse XP as indicated by their lack of blue colour. These two B. pseudomallei phosphatase-negative mutants were designated APM402 and APM403. The DNA flanking the Tn5-OT182 integrations in each of these mutants was isolated by self-cloning using EcoRI and HindIII. The resulting plasmids were isolated and single-stranded sequence reactions were carried out. The sequences obtained were analysed using the BLASTX local alignment search tool. The sequence from APM403 demonstrated a high degree of homology to the AP of Francisella tularensis var. novicida. In contrast, the sequence from APM402 showed no significant homology to any sequences currently in the GenBank database.

The self-cloned plasmids, pAPM403E and pAPM403H (Fig. 1a), were sequenced for approximately $2 \mathrm{~kb}$ on each side of the Tn5-OT182 integration on both strands using a primer walking strategy. An ORF of 1734 nucleotides was identified. The product of this ORF demonstrated $36 \%$ similarity to the acpA gene of $F$. tularensis and was therefore designated the $B$. pseudomallei acpA gene homologue. PCR primers were designed based on this sequence in order to identify the acp A gene homologues of B. thailandensis and B. mallei, both of which exhibit phosphatase activity. This approach was successful for identification of the $B$. malle $i$ acp $A$ homologue, but ineffective for identifying the $B$. thailandensis acpA homologue. The PCR product obtained from B. mallei ATCC 23344 chromosomal DNA using the AP-5' and AP-3' primers migrated to the 


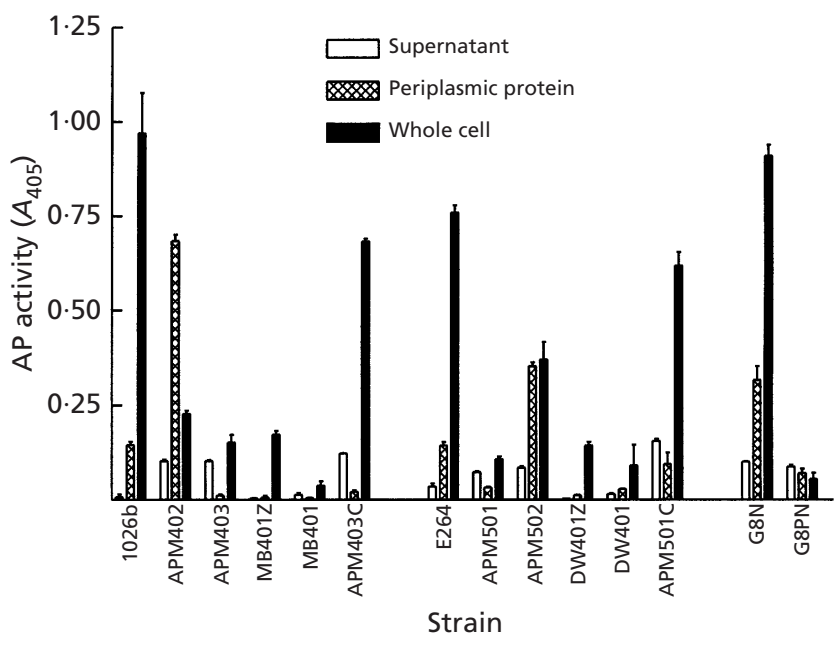

Fig. 2. AP activities of the $B$. pseudomallei, B. thailandensis and $B$. mallei strains used in this study. Supernatant, periplasmic and whole-cell fractions were prepared from overnight cultures grown at $37^{\circ} \mathrm{C}$. See Methods for details. The values are means and standard deviations of a single experiment performed in triplicate.

same position as the B. pseudomallei $1026 \mathrm{~b}$ PCR product on a $1 \%$ agarose gel; both were approximately $1.8 \mathrm{~kb}$ in size. This result indicated that the acpA gene homologues present in both $B$. pseudomallei and B. mallei were probably very similar. These products were cloned and subjected to sequence analysis, which confirmed them to be acpA homologues. The sequence of the $B$. mallei acp $A$ homologue was then completed on both strands.

Since we were unable to obtain a $B$. thailandensis acp $A$ homologue by PCR, we chose to employ Tn5-OT182 mutagenesis to isolate this gene. Approximately 5000 Tn5-OT182 mutants of B. thailandensis E264 were plated onto LB agar plates containing XP and two white mutants were obtained. These mutants were designated APM501 and APM502. The chromosomal DNA immediately flanking the Tn5-OT182 integrations in these mutants was obtained by self-cloning using Sst $\mathrm{I}$ and HindIII. The sequences obtained from pAPM501Ss and pAPM501H demonstrated highest homology to the $B$. pseudomallei acpA gene homologue. Primer walking was employed to sequence the $B$. thailandensis acp $A$ homologue on both strands. The sequence from the $B$. thailandensis APM502 was shown to have highest homology to the UDP-rfaH intergenic region of E. coli.

\section{AP activity of B. pseudomallei, B. thailandensis and B. mallei strains}

AP activity has previously been characterized for $B$. pseudomalle $i$ and it has been shown that optimal activity occurs at pH 5.5 and at $37^{\circ} \mathrm{C}$ (Kanai \& Kondo, 1994; Kondo et al., 1991a, 1996). To confirm that the mutant strains isolated in this study lacked any AP activity, both the parent strains and the mutant strains were assayed as described in Methods (Fig. 2). All three parent strains, B. pseudomallei 1026b, B. thailandensis E264 and B. mallei ATCC 23344, demonstrated similar levels of AP activity. The results of this assay indicated that the Tn5-OT182 mutants, APM403 and APM501, lacked any observable AP activity. In contrast, APM402 had considerable AP activity restricted to the periplasmic fraction and APM502 retained observable amounts of AP activity in both the periplasmic and whole-cell fractions.

\section{Nucleotide sequence analysis of the acpA genes of B. pseudomallei, B. thailandensis and B. mallei}

The nucleotide sequences of the $a c p A$ gene homologues from B. pseudomallei 1026b, B. thailandensis E264 and B. mallei ATCC 23344 demonstrated $23 \%$ identity and $36 \%$ similarity with the acpA gene product of $F$. tularensis. A 1734 bp ORF was identified, beginning with the ATG codon and ending with the TGA codon, that was consistent for B. pseudomallei and B. mallei, while a GTG start codon was identified for $B$. thailandensis. The $\mathrm{G}+\mathrm{C}$ content of the acpA ORF was determined to be $69 \mathrm{~mol} \%$. A putative Shine-Dalgarno sequence was identified -6 to -10 bp upstream of the putative ATG/GTG start codons, suggesting that these are the correct start sites. The nucleotide sequences obtained for B. thailandensis and B. malle $i$ were $94 \%$ and $99 \%$ identical, respectively, to the B. pseudomalle $i$ acpA sequence. The Tn5-OT182 integration associated with APM403 occurred at nucleotide 1633 of the acpA ORF while the Tn5-OT182 integration associated with APM501 occurred at nucleotide 365. The approximate positions are shown in Fig. 1(a). The putative protein encoded by acp $A$ was predicted to be 578 amino acids in length with a calculated molecular mass of $62860 \mathrm{Da}$. Comparison of the predicted amino acid sequences of B. thailandensis AcpA and B. mallei AcpA to that of the B. pseudomallei AcpA predicted amino acid sequence revealed 15 and 3 differences, respectively. This reflects the close phylogenetic relationship between these species.

\section{Characterization of AP-negative allelic exchange mutants}

AP-negative mutants were constructed by allelic exchange as previously described with $B$. pseudomalle $i$ DD503 and B. thailandensis DW503 using the vectors p46MB401Z or p46MB401X (Fig. 1b). These vectors contained a portion of the acp $A$ gene including nucleotides $1140-1633$ along with $1.5 \mathrm{~kb}$ of upstream DNA that has not yet been sequenced. The B. pseudomallei $\triangle a c p A$ mutants were designated MB401Z and MB401 and the $B$. thailandensis $\triangle a c p A$ mutants were designated DW401Z and DW401. The strains MB401 and DW401 have a deletion in their acpA genes and lack the oriZeo marker present in the other AP-negative allelic exchange mutants, thus eliminating the need for the presence of $\mathrm{Ze}$ in selective media. As described in Methods, a slightly different strategy using the p46MB401Z vector was employed for allelic exchange in B. mallei. The 
oriZeo cassette was used for positive selection in $B$. mallei allelic exchange and $\mathrm{Ze}$ was used in further experiments. The resulting $\triangle a c p A$ strain of $B$. malle $i$ was designated G8PN and was assessed for AP activity.

The isogenic allelic exchange mutant strains MB401Z/ MB401, DW401Z/DW401 and G8PN were unable to hydrolyse the chromogenic substrate XP when present in LB or TSG agar. This was consistent with the observation that Tn5-OT182 disruptions in the acpA homologue caused APM403 and APM501 to display a white phenotype. Additionally, the allelic exchange mutants were essentially devoid of AP activity at $\mathrm{pH} 5 \cdot 5$ (Fig. 2) compared to wild-type strains. The inability of these strains to display blue colour when grown on agar containing XP made them good candidates as recipients for mutagenesis with $\operatorname{Tn} p h o A$ and thus for the identification of exported products.

\section{Complementation of AP-negative Tn5-OT182 strains}

The $1.8 \mathrm{~kb}$ PCR product harbouring the acpA gene homologue $B$. pseudomallei was cloned into pUCP29T and was conjugated to B. pseudomallei APM403 and B. thailandensis APM501. The presence of p29acpA was able to restore the AP activity of these strains. The complemented strains, designated APM403C and APM501C, were blue when grown on LB agar plates containing XP and exhibited activity by AP activity assay (Fig. 2). These results indicate that the AP-negative phenotype observed in APM403 and APM501 is due to the Tn5-OT182 disruption in their acpA gene homologues and that this gene encodes a product that is responsible for the AP activity observed in these organisms. The strains constructed for TnphoA mutagenesis were not complemented as the mutation encompasses $2.8 \mathrm{~kb}$ that has not been completely sequenced.

\section{TnphoA and mini-OphoA mutagenesis of B. pseudomallei, B. thailandensis and B. mallei}

Two Tn5-based transposons containing truncated $p h o A$ genes were employed in this study. Initially, TnphoA was delivered to MB401Z, DW401Z and G8PN on the vector pRT733 as previously described (Taylor et al., 1989). This system worked efficiently for B. pseudomalle $i$ and $B$. thailandensis, resulting in approximately 1000-1200 $\mathrm{Sm}^{\mathrm{R}} \mathrm{Km}^{\mathrm{R}}$ transconjugants per mutagenesis experiment, $1 \%$ of which were PhoA positive. However, in B. mallei, the TnphoA transposition frequency was significantly lower: each mutagenesis resulted in only $50-200 \mathrm{Nx}^{\mathrm{R}} \mathrm{Km}^{\mathrm{R}}$ transconjugants with a frequency of PhoA-positive colonies of approximately $2 \%$. Southern blot analysis using BamHI-digested chromosomal DNA from TnphoA mutants confirmed that TnphoA integrated only once per chromosome in four randomly selected $B$. pseudomallei and $B$. thailandensis PhoA-positive mutants.

Although this system is functional in these strains, the cloning procedures had a low efficiency, approximately
$25 \%$. This is suspected to be due in part to the size of the transposon and the fact that the cloning vector, pBR322, has a size limit on the DNA inserts that it can efficiently accept (approx. $7 \mathrm{~kb}$ ). Upon digestion of the chromosomal DNA of PhoA-positive mutants with BamHI or SalI at least $5 \mathrm{~kb}$ of transposon remains along with the chromosomal DNA immediately flanking fragment. The cloning of DNA fragments containing TnphoA and adjacent chromosomal DNA into pBR322 resulted in only relatively small $(<2 \mathrm{~kb})$ flanking DNA sequences being obtained. The resulting plasmids were sequenced and BLASTX searches were performed. Sequences showing significant homology over at least $300 \mathrm{bp}$ of flanking DNA are shown in Table 2.

Due to the low numbers of transconjugants in $B$. mallei Tn $p h o A$ mutagenesis experiments, we chose to employ a second transposon, designated mini-OphoA (Bolton $\&$ Woods, 2000). The mini-OphoA system was found to be equivalent in transposition frequency to $\operatorname{Tn} p h o A$ in $B$. pseudomallei and B. thailandensis, with the occurrence of PhoA-positive colonies being $0.5 \%$. The transposition frequency was increased in $B$. mallei: approximately $1500 \mathrm{Ze}^{\mathrm{R}} \mathrm{Nx}^{\mathrm{R}} \mathrm{Gm}^{\mathrm{R}}$ transconjugants were obtained per mutagenesis, with the frequency of PhoA-positive colonies being $2 \%$. In addition, due to the presence of an origin of replication, the cloning procedures for obtaining the DNA sequences flanking mini-OphoA integrations were simpler and more efficient than those for TnphoA. Cloning efficiency was $90 \%$ when chemically competent E. coli Top 10 cells (Invitrogen) were used. The chromosomal DNA of six random $\mathrm{Sm}^{\mathrm{R}} \mathrm{Gm}^{\mathrm{R}}$ transconjugants of $B$. pseudomalle $i$ and $B$. thailandensis and three random $\mathrm{Ze}^{\mathrm{R}} \mathrm{Nx}^{\mathrm{R}} \mathrm{Gm}^{\mathrm{R}}$ transconjugants of $B$. malle $i$ was isolated, digested with NotI and probed with $\alpha-{ }^{32} \mathrm{P}$-labelled mini-OphoA. All nine mutants contained single copies of this transposon, suggesting that mini-OphoA integrates randomly into the chromosomes of $B$. pseudomallei, B. thailandensis and B. mallei.

The DNA from a number of PhoA-positive $B$. pseudomallei, B. thailandensis and B. mallei mini$\mathrm{O} p h o A$ mutants was self-cloned and subjected to singlestranded sequencing in order to characterize the DNA flanking the transposon integrations. Approximately 500-700 bp of sequence was obtained on each side of the mini-OphoA integrations. Subsequently, database searches were performed in order to establish homologies to known gene sequences. Some of the sequences obtained from the Pho-LT primer demonstrated significant homology over at least $300 \mathrm{bp}$ and are shown in Table 2. A number of putative genes were identified which encoded proteins showing homology to secreted proteins, confirming the ability of this system to identify extracytoplasmic products expressed by the three Burkholderia spp. utilized in this study.

The DNA sequences adjacent to TnphoA and miniOphoA integrations in a number of PhoA-positive mutants did not show any significant homology to sequences currently in the GenBank database. These 
Table 2. Table of homology of TnphoA and mini-OphoA flanking sequences

\begin{tabular}{|c|c|c|c|c|}
\hline $\begin{array}{l}\text { PhoA-positive } \\
\text { mutant }\end{array}$ & $\begin{array}{l}\text { Identity } \\
\quad(\%)\end{array}$ & $\begin{array}{l}\text { Similarity } \\
(\%)\end{array}$ & Homology & Entrez protein ID \\
\hline \multicolumn{5}{|c|}{ B. pseudomallei $\operatorname{Tn} p h o A$ mutants } \\
\hline PHOA8 & 40 & 43 & Putative cell wall protein of Streptomyces coelicolor & AL137165 \\
\hline PHOA16 & 99 & 99 & gspG (B. pseudomallei) type II secretion pathway gene & AAD05177.1 \\
\hline PHOA20 & 23 & 33 & Hydroxyproline-rich glycoprotein of Zea diploperennis & 228938 \\
\hline PHOA39 & 31 & 38 & $\begin{array}{l}\text { ExiT protein (exochelin } \mathrm{ABC} \text { transporter) from Mycobacterium } \\
\text { smegmatis }\end{array}$ & AAC32046.1 \\
\hline PHOA47 & 32 & 50 & Outer-membrane protein C of Pseudomonas aeruginosa & BAA05664.1 \\
\hline \multicolumn{5}{|c|}{ B. mallei Tnpho $A$ mutant } \\
\hline AJB34 & 75 & 95 & Dipeptide transport system permease protein of Escherichia coli & AAC76568.1 \\
\hline \multicolumn{5}{|c|}{ B. pseudomallei mini-Opho $A$ mutants } \\
\hline PHOG4 & 33 & 43 & Penicillin-binding protein of Deinococcus radiodurans & AAF10059.1 \\
\hline PHOG9 & 45 & 63 & Periplasmic serine protease from Aquifex aeolicus & AAC07399.1 \\
\hline PHOG18 & 52 & 76 & $\begin{array}{l}\text { Putrescine-binding periplasmic protein precursor; permease } \\
\text { protein from Escherichia coli }\end{array}$ & AAC73941.1 \\
\hline PHOG28 & 69 & 84 & $\begin{array}{l}\text { Phosphate-binding periplasmic protein precursor of Erwinia } \\
\text { carotovora }\end{array}$ & AAB70458.1 \\
\hline PHOG29 & 37 & 50 & Outer-membrane porin protein OpcP1 of Burkholderia cepacia & BAA09892.1 \\
\hline \multicolumn{5}{|c|}{ B. thailandensis mini-Opho $A$ mutants } \\
\hline PHOG103 & 36 & 44 & $\begin{array}{l}\text { Putative YME1 ATP-dependent zinc protease of Arabidopsis } \\
\text { thaliana }\end{array}$ & AAC31223.1 \\
\hline \multicolumn{5}{|c|}{ B. mallei mini-Opho $A$ mutant } \\
\hline AJB101 & 43 & 56 & $\begin{array}{l}\text { Probable ABC transporter, permease protein of Treponema } \\
\text { pallidum }\end{array}$ & F71375 \\
\hline AJB116 & 40 & 60 & $\begin{array}{l}\text { Branched-chain amino acid } \mathrm{ABC} \text { transporter of Deinococcus } \\
\text { radiodurans }\end{array}$ & H75444 \\
\hline AJB139 & 69 & 80 & Phosphate-binding protein of Enterobacter cloacae & BAA22861.1 \\
\hline AJB150 & 36 & 50 & $\begin{array}{l}\text { Putative aromatic efflux pump outer-membrane protein of } \\
\text { Sphingomonas aromaticivorans }\end{array}$ & AAD03862.1 \\
\hline AJB153 & 60 & 73 & $\begin{array}{l}\text { Periplasmic sorbitol-binding protein of Rhodobacter } \\
\text { sphaeroides }\end{array}$ & AAC45766.1 \\
\hline AJB171 & 63 & 75 & Outer-membrane protein $\mathrm{C}$ of Pseudomonas aeruginosa & BAA05664.1 \\
\hline
\end{tabular}

sequences are of significant interest and may represent as yet undefined genes encoding exported products.

\section{DISCUSSION}

The AP activity of $B$. pseudomallei has been previously documented (Kanai \& Kondo, 1994; Kondo et al., 1991a, b, 1996); however, the gene responsible for this activity had not been identified prior to this study. The present work has demonstrated the presence of acpA gene homologues in B. pseudomallei, B. thailandensis and $B$. mallei. A simple screen was employed to identify mutants devoid of phosphatase activity. Several Tn5OT182 mutants unable to hydrolyse XP were isolated and these subsequently facilitated the identification of acp $A$ gene homologues in both $B$. pseudomallei and $B$. thailandensis. PCR primers designed from the nucleotide sequence of the $B$. pseudomallei acp $A$ gene allowed the identification of an acp $A$ homologue from $B$. mallei. The acp $A$ genes from the species used in this study were sequenced and the predicted amino acid compositions reflected the close phylogenetic relationship between these species. Complementation analyses have shown that functional acpA gene homologues are required for AP activity in these three Burkbolderia spp. Furthermore, identification of acpA genes in these species has allowed the construction of strains with $\triangle a c p A$ genes through allelic exchange.

The AP-negative strains constructed in this study have been used for mutagenesis experiments employing Tn5based transposons containing truncated pho $A$ genes. The B. thailandensis strain DW401/DW401Z will be particularly useful as it is a non-virulent strain that can be used as a laboratory tool for the identification of genes likely to be present in the highly virulent, closely related $B$. pseudomalle $i$ and $B$. malle $i$ strains. The results of this study clearly indicate that Tn5-based transposons containing truncated $p h o A$ genes can be efficiently used in B. pseudomallei and B. thailandensis strains. It is not clear why $\operatorname{Tn} p h o A$ mutagenesis was not effective in $B$. 
mallei; it may be due to an incompatibility with the vector carrying the transposon. However, this problem was overcome by employing a second transposon system, mini-OphoA, that was shown to integrate efficiently in this species.

PhoA-positive transposon mutants have been isolated in this study and sequence analysis of DNA flanking transposon insertions has revealed homology to a number of known gene sequences. We have demonstrated that the $p h o A$ fusion approach can be efficiently used in Burkholderia spp. for the identification of genes encoding exported proteins. The phoA systems employed in this study have facilitated the identification of genes potentially contributing to the pathogenesis of melioidosis and glanders. We are currently constructing isogenic mutants in specific genes identified via phoA mutagenesis; this will allow for the assessment of the contribution of particular genes to the phenotypes displayed by these organisms. Such mutants will be used in virulence testing. This will help to establish the roles specific exported products play in pathogenesis.

Preliminary studies on the role of the acp $A$ gene product in the pathogenesis of $B$. pseudomallei and $B$. mallei infections indicate that the disruption of the acpA gene does not significantly alter virulence (data not shown). The mutants harbouring disrupted acpA genes may be useful for future studies regarding the specific functioning of the $\operatorname{acp} A$ gene and its product. Identification of the $a c p A$ gene and the subsequent implementation of phoA mutagenesis systems described in the present study will contribute to the continuing studies on the pathogenesis of melioidosis and glanders.

\section{ACKNOWLEDGEMENTS}

This research is supported by the Canadian Bacterial Diseases Network Centers for Excellence. M. N.B. is the recipient of an Alberta Heritage Foundation for Medical Research (AHFMR) studentship. D.W. is the recipient of an AHFMR summer studentship.

\section{REFERENCES}

Altschul, S., Madden, T., Schaffer, A., Zhang, J., Zhang, Z., Miller, W. \& Lipman, D. (1997). Gapped BLAST and PSI-BLAST: a new generation of protein database search programs. Nucleic Acids Res 25, 3389-3402.

Ames, G. F., Prody, C. \& Kustu, S. (1984). Simple, rapid, and quantitative release of periplasmic proteins by chloroform. $J$ Bacteriol 160, 1181-1183.

Arun, S., Neubauer, H., Gurel, A., Ayyildiz, G., Kuscu, B., Yesildere, T., Meyer, H. \& Hermanns, W. (1999). Equine glanders in Turkey. Vet Rec 144, 255-258.

Bolton, A. J. \& Woods, D. E. (2000). A self-cloning minitransposon phoA gene fusion system promotes the rapid analysis of secreted proteins in Gram negative bacteria. Biotechniques 29, 470-474.

Bondre, V.P., Srivastava, R., Sinha, V. B. \& Srivastava, B. S. (1997). Screening of TnphoA mutants of Vibrio cholerae O139 for identification of antigens involved in colonisation. $J \mathrm{Med}$ Microbiol 46, 1007-1011.

Brett, P. J., DeShazer, D. \& Woods, D. E. (1998). Burkholderia thailandensis sp. nov., a Burkholderia pseudomallei-like species. Int J Syst Bacteriol 48, 317-320.

Dennis, J. J. \& Zylstra, G. J. (1998). Plasposons: modular selfcloning minitransposon derivatives for rapid genetic analysis of gram-negative bacterial genomes. Appl Environ Microbiol 64, 2710-2715.

DeShazer, D., Brett, P. J., Carlyon, R. \& Woods, D. E. (1997). Mutagenesis of Burkholderia pseudomallei with Tn5-OT182: isolation of motility mutants and molecular characterisation of the flagellin structural gene. J Bacteriol 179, 2116-2125.

DeShazer, D., Brett, P. J., Burtnick, M. N. \& Woods, D. E. (1999). Molecular characterisation of genetic loci required for secretion of exoproducts in Burkholderia pseudomallei. J Bacteriol 181, 4661-4664.

Hsia, R. C., Small, P. L. \& Bavoil, P. M. (1993). Characterisation of virulence genes of enterinvasive Escherichia coli by TnphoA mutagenesis : identification of $i n v X$, a gene required for entry into HEp-2 cells. J Bacteriol 175, 4817-4823.

Kanai, K. \& Kondo, E. (1994). Recent advances in biomedical sciences of Burkholderia pseudomallei (basonym: Pseudomonas pseudomallei). Jpn J Med Sci Biol 47, 1-45.

Kondo, E., Dejsirilert, S., Wejprasit, N., Chiewsilp, D. \& Kanai, K. (1991a). Heat-stable and heat-labile components of nonspecific acid phosphatase detected in Pseudomonas pseudomallei. Jpn J Med Sci Biol 44, 51-62.

Kondo, E., Petkanchanapong, V., Naigowit, P., Kurata, T. \& Kanai, K. (1991b). Demonstration of acid phosphatase activity in antigenic glycoprotein fractions obtained from the culture filtrate of Pseudomonas pseudomallei. Jpn J Med Sci Biol 44, 213-224.

Kondo, E., Kurata, T., Naigowit, P. \& Kanai, K. (1996). Evolution of cell-surface acid phosphatase of Burkholderia pseudomallei. Southeast Asian J Trop Med Public Health 27, 592-599.

Manoil, C. \& Beckwith, J. (1985). TnphoA: a transposon probe for protein export signals. Proc Natl Acad Sci U S A 82, 8129-8133.

Merriman, T. R. \& Lamont, I. L. (1993). Construction and use of a self-cloning promoter probe vector for gram-negative bacteria. Gene 126, 17-23.

Miller, V. L. \& Mekalanos, J. J. (1988). A novel suicide vector and its use in construction of insertion mutations: osmoregulation of outer membrane proteins and virulence determinants in Vibrio cholerae requires toxR. J Bacteriol 170, 2573-2583.

Milner, J. S., Dymock, D., Cooper, R. M. \& Roberts, I. S. (1993). Penicillin-binding proteins from Erwinia amylovora: mutants lacking PBP2 are avirulent. J Bacteriol 175, 6082-6088.

Moore, R. A., DeShazer, D., Reckseidler, S. L., Weissman, A. \& Woods, D. E. (1999). Efflux-mediated aminoglycoside and macrolide resistance in Burkholderia pseudomallei. Antimicrob Agents Chemother 43, 465-470.

Morgenstern, B. (1999). DIALIGN 2: improvement of the segment-to-segment approach to multiple sequence alignment. Bioinformatics 15, 211-218.

Reckseidler, S. L., DeShazer, D., Sokol, P. A. \& Woods, D. E. (2001). Detection of bacterial virulence genes by subtractive hybridisation: identification of the capsular polysaccharide of Burkholderia pseudomallei as a major virulence determinant. Infect Immun 69 (in press).

Rubino, S., Leori, G., Rizzu, P., Erre, G., Colombo, M. M., Uzzau, S., Masala, G. \& Cappuccinelli, P. (1993). TnphoA Salmonella abortusovis mutants unable to adhere to epithelial cells with reduced virulence in mice. Infect Immun 61, 1786-1792.

Schweizer, H., Klassen, T. \& Hoang, T. (1996). Improved methods for gene analysis and expression in Pseudomonas spp. In 
Molecular Biology of Pseudomonads, pp. 229-237. Edited by T. Nakazawa, K. Furukawa, D. Haas \& S. Silver. Washington, DC: American Society for Microbiology.

Skorupski, K. \& Taylor, R. K. (1996). Positive selection vectors for allelic exchange. Gene 169, 47-52.

Smith, C., Allen, J., Embi, M., Othman, O., Razak, N. \& Ismail, G. (1987). Human melioidosis: an emerging medical problem. MIRCEN J Appl Microbiol Biotechnol 3, 343-366.

Taylor, R. K., Manoil, C. \& Mekalanos, J. J. (1989). Broad-host- range vectors for delivery of $\operatorname{Tn} p h o A$ : use in genetic analysis of secreted virulence determinants of Vibrio cholerae. I Bacteriol 171, 1870-1878.

Weiser, J. N. \& Gotschlich, E. C. (1991). Outer membrane protein A (OmpA) contributes to serum resistance and pathogenicity of Escherichia coli K-1. Infect Immun 59, 2252-2258.

Received 27 June 2000; revised 12 September 2000; accepted 5 October 2000. 